\title{
The Pandemic, Ecological Justice, and Zhu Xi's Philosophy
}

\author{
Seongmin HONG*
}

\begin{abstract}
COVID-19 has brought many changes to society and encouraged mankind to reflect on its civilization. The pandemic has revealed that our health care systems and community solidarity are far more fragile than we believed. It made us rethink the solidarity of human civilization and community, and more fundamentally, reconsider the global ecosystem beyond human society. This paper claims that COVID-19 was an inevitable result of the anthropocentric perspective, and argues that it is necessary to change the perception to an ecological worldview and practice ecological justice in order to solve this situation. First, it analyses the ecological reasons for the regular outbreak of zoonotic diseases, including COVID-19, and then it examines Naess's deep ecology with regard to a fundamental change of perception, but also finds several weaknesses in this. Third, this paper focuses on Zhu Xi's philosophy in order to compensate for the weaknesses of deep ecology. It argues for the importance of human roles and obligations in relation to the safety and health of the environment based on his philosophy, and explains ecological justice by applying his social equality theory to ecology. Finally, it sheds new light on Zhu Xi's theory of investigation of things (gerwu 格物) as a practical way of implementing ecological justice.
\end{abstract}

Keywords: pandemic, ecological justice, deep ecology, investigation of things, self-realization

\section{Pandemija, ekološka pravičnost in Zhu Xijeva filozofija}

\section{Izvleček}

COVID-19 je prinesel številne družbene spremembe in človeštvo spodbudil k razmisleku o njegovi civilizaciji. Pandemija je razkrila, da so naši sistemi zdravstvenega varstva in skupnostna solidarnost veliko krhkejši, kot smo mislili. Primorala nas je v ponoven razmislek o solidarnosti znotraj človeške civilizacije in skupnosti ter v še temeljnejši razmislek o globalnih ekosistemih onkraj človeških družb. Članek trdi, da je bolezen COVID-19 neizogibna posledica antropocentričnega pogleda, in utemeljuje, da je treba za rešitev tega položaja spremeniti naše dojemanje v ekološki svetovni nazor in prakticirati ekološko pravičnost. Članek najprej analizira ekološke razloge za redne izbruhe zoonotičnih bolezni,

Seongmin HONG, Department of Philosophy,

Hankuk University of Foreign Studies.

Email address: hmean@hanmail.net

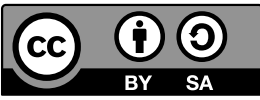


vključno s COVID-19, nato pa prouči Naessovo globinsko ekologijo, s poudarkom na temeljni spremembi dojemanja, pri čemer ugotovi tudi nekaj pomanjkljivosti. Tretjič, članek se osredotoča na Zhu Xijevo filozofijo, da bi nadomestil slabosti globinske ekologije. $\mathrm{Na}$ podlagi njegove filozofije utemeljuje pomen človekovih vlog in obveznosti v odnosu do varnosti in zdravja okolja ter ekološko pravičnost pojasnjuje $z$ uporabo njegove teorije družbene enakosti v ekologiji. Na koncu na novo osvetli Zhu Xijevo teorijo raziskovanja stvari (gewu 格物) kot praktični način vpeljave ekološke pravičnosti.

Ključne besede: pandemija, ekološka pravičnost, globinska ekologija, raziskovanje stvari, samorealizacija

\section{Introduction}

COVID-19 brought many unexpected changes to society. People's meetings were controlled, cities were shut down, unemployment rose and community trust was broken. Unfounded hatred and violence against Asians also broke out in many places. Fortunately, a vaccine has been developed and is being used, but the fear and anxiety are not diminishing because mutated viruses, including the delta variant, appear one after another. Moreover, even if COVID-19 is over, no one can guarantee that there will be no more new viruses that cause a pandemic. The anxiety and danger to society may persist for a very long time. This is worrisome, in that it is a sign of a serious and unprecedented rift in the human community.

If these concerns are even a little true, what we need to worry about now is not the superficial question of how to combat the COVID-19 virus. We need to find a fundamental way to strengthen the solidarity of the human community in order to lead a social life without problems, despite the constant threat of the virus. In particular, considering that these infectious diseases are not selectively transmitted to a specific country or society, but threaten the entire planet, it is necessary to be clearly aware that all human beings are under one fate and have a sense of camaraderie toward them all. In response to COVID-19, Rošker says:

This emergency demonstrates that we live in an extremely interdependent world. A thorough recognition of our vital mutual connections and common threats can certainly help us to find a way out of the global crisis. On the other hand, a failure to value our tight interconnections may even prolong its dangers instead of eliminating them. ... we must spread the awareness that we are all parts of global humanity, and hence we are all in the same boat: we sink or swim together. Therefore, it is also 
necessary to nurture a sensitivity and empathy for our fellow human beings who might be suffering. (Rošker 2021, 65, 74)

Her exhortation is timely and insightful. In order to end COVID-19, or even if that cannot be achieved, then for the safety of all, the path we must take is the solidarity and cooperation of all mankind. The members of that solidarity must be all the people of the world, transcending nationalities, cultures, religions, and classes. If even some of us do not enter the safe zone of quarantine, the threat of COVID-19 will never end and can spread again. The safety of individuals will be guaranteed only when the scope of solidarity for quarantine is expanded to the fullest extent to all mankind.

Furthermore, if we think about it more fundamentally and comprehensively, it seems that the scope of solidarity should be expanded beyond mankind. It is necessary to expand the scope of our community to nature and consider solidarity with the ecological world. This is because viruses do not occur between human beings, but at the point where we and nature come into contact, and are created when we invade the ecological habitat of wild animals. Therefore, only when we pay attention to and preserve ecosystems can we fundamentally prevent a resurgence of this or another virus. In short, only when the scope of solidarity extends beyond mankind to the entire global ecosystem can we truly be safe from the novel viruses such as COVID-19.

This article attempts to assert that the fundamental prescription for us to get out of the pandemic is the formation of an ecological community. The prescription for this should include not only a shift in perception towards an ecological worldview, but also the practice of ecological justice. The term 'ecological justice' means the state in which all beings are in harmony while living their own lives contentedly without infringement, in other words, suum cuique in ecology. Obviously, in order to form and maintain a social community, a form of justice that guarantees 'to each what rightfully belongs to him or her' in the community must be adopted. Likewise, for an ecological community in which humans and nature coexist, a form of ecological justice that enables all beings to live their own optimal lives must be prioritized. This requires efforts to understand each living thing in an ecosystem in detail and treat them appropriately, away from anthropocentric, selfish and biased interests. To this end, this paper will focus on Zhu Xi's (朱喜) philosophy. The reason for paying attention to this is that he not only constructed an elaborate metaphysics of life, but also presented it as an ecological ethics in the real world and emphasized the concrete, practical actions people can take for ecological welfare. 
This article will first look at the ecological reasons for the steady outbreak of zoonotic diseases, including COVID-19, and will then examine Naess's concept of deep ecology with regard to making the fundamental change toward an ecological worldview. Third, in order to address the weaknesses of Naess's argument, it will examine our roles and moral obligations as ecological subjects for the safety and health of the whole ecological community by focusing on Zhu's philosophy. Fourth, it will illuminate the idea of ecological justice by applying Zhu's social equality theory to ecology. Finally, it will elucidate Zhu's theory of investigation of things (gewu 格物) as a practical way of implementing ecological justice.

\section{The Ecological Cause of the Pandemic}

The recently invented COVID-19 vaccines could be an exit from the dark tunnel of the pandemic. In addition, various medicines being developed around the world show hope that we will completely overcome COVID-19. Already, the UK and other European countries have lifted social restrictions through the use of vaccination, while Singapore and China have eased controls, too. South Korea is also expected to declare "With CORONA" around November 2021 and relax restrictions. Is the pandemic thus coming to an end? Probably not. This relief and optimism are only limited to COVID-19. If we think about when a new coronavirus will break out and plunge the world into a pandemic again, the relief of today will not last long. This is not pessimism, but a predictable fact given the recent history of coronaviruses.

In November 2002, SARS emerged in Guangdong Province (廣東省), China, which shocked Asian countries. In March 2009, an outbreak of swine flu influenza in San Diego, USA, terrified the world, In April 2012, MERS-CoV occurred in Saudi Arabia, causing many casualties, and in December 2019, COVID-19 in Wuhan (武漢), China, plunged the world into the darkness of today's pandemic. In fact, new viruses are discovered every 3-6 years, but mankind is not prepared for them at all.

One biologist predicts that the cycle of infectious diseases will become shorter in the future, and new ones will emerge every three years or even each year (Choi 2020, 32). Although vaccines and medicines for COVID-19 may be short-term prescriptions, they cannot be a fundamental and structural solution ( $\mathrm{Ha} 2020,101)$. Are consecutive contagions a fatal disaster that cannot be stopped by human power? It doesn't seem so. If you think about the reasons why coronaviruses have been spreading one after another, you can see that this is because of human error. Because these diseases are closely related to the development of human civilization. 
All the diseases that pose a great threat to mankind are zoonotic, coming from animals. The Black Death, which killed 20 million people between 1347 and 1351, came from rat fleas; the Spanish flu of 1918, which killed 25-50 million people, from pigs and birds. H1N1 influenza is believed to have originated from pigs, the Ebola virus from bats and gorillas, MERS-CoV from bats and camels (Quammen 2012, 30), and COVID-19 from bats and pangolins, although the details are not yet known.

The origins of these epidemics that caused so much death are all animals. Animal viruses are transmitted and transformed in human beings, causing serious damage. However, if an ecosystem operates stably, then pathogens are only preserved in the body of the host without any problems. But when there is a change in an ecosystem, hidden pathogens are exposed and become the cause of infectious diseases. Rapid changes in ecosystems come from mankind. As we destroy ecosystems and invade animal habitats, people and animals naturally encounter each other, and in the process the latent viruses in the host's body are released and can cause disease.

It is an optical illusion or myopia that defines today's pandemic as only due to a sort of virus from the natural world named COVID-19. Considering the outbreak of the pandemic and resulting global fear, we can see that it has more comprehensive causes and conditions. It is not difficult to understand that all zoonotic diseases, including COVID-19, were caused by the production-consumption structure of modern industrial civilization and capitalism. According to the UN Environmental Programme, zoonotic diseases originate entirely from human actions. For example, deforestation and other land use changes, illegal and poorly regulated wildlife trade, climate change, antimicrobial resistance, intensified agriculture, and livestock production, are all factors of that increase the number of zoonotic diseases (UNEP 2020). In addition, Lee Humber analyses the impact of modern industrial factory farming on the outbreak of the virus. According to him, the genetic monoculture of animals that has developed for increased productivity and ease of management removes the firebreak of immunity, and species without diversity are vulnerable to viruses, making common zoonotic diseases spread faster and stronger (Humber 2020). In short, industrial practices inherent in the capitalist mode of production, now globalized and intensified by 50 years of neoliberalism, are actively breeding more and more virulent and deadly pathogens. This pattern of epidemics is not accidental (ibid.), and the consequences of destroying ecosystems to achieve human goals have returned as a disaster (Im 2006, 76).

As ecosystems were destroyed due to industrialization and land development, the nature inhabited by wild animals such as bats was transformed into farmland, pastureland, factory sites, and residential areas, drawing wild 
animals closer to the realm of human activity. The destruction of ecosystems, such as the destruction of forest resources and clearing and cultivation of native land, also expands contact areas with wild animals, increasing the possible spread of zoonotic diseases. In addition, as the population density increases due to urbanization and the movement of the population increases due to the development of transportation, infectious diseases can spread more rapidly and to a wider area (Jeong 2020,213).

Industrialism and capitalism use anything as a production material for profit. They regard natural ecosystems only as materials and resources, and consume them until they are exhausted. Developmentalism has focused only on short-sighted interests, and even turned the ecosystem into a resource, with the consequences now being seen. In this respect, the virus should be defined as a social disease, not just a biological one, and the treatment and prevention of the virus should be recognized as a political and economic problem, not simple a medical one (Kim 2020, 125).

So, what about sustainable development? But this would also be a "shallow" fiction. Although sustainable development theory has brought environmental and ecological problems into the debate, its focus remains on development. This socalled "environment-friendly" development theory regards development as the top priority, and any ecological and environmental problem as secondary. Such a theory runs the risk of being employed as logic to justify development at all costs. But sustainable development theory also remains based on the anthropocentric viewpoint, in that it is centred on the prioritization of man's exclusive interests at the expense of the ecosystem as a whole. Ecological theory is rooted in the perception of man and nature as equal beings. Viewed from this standpoint, any sustainable development theory that seeks to develop and preserve nature based on man's needs cannot be regarded as ecological or as having ecological ethics (Hong 2011, 17). Therefore, it is necessary to change the very fundamental perception of ecology and people.

So, why do people do these things that harm the environment and ultimately themselves? The root cause lies in the view of nature. The medieval historian Lynn White has suggested that the emphasis in Judaism and Christianity on the transcendence of God above nature and the dominion of humans over nature has led to a devaluing of the natural world, and a subsequent destruction of its resources for utilitarian ends (White 1967, 1203-7; Tucker and Grim 1998, xxv). His words may go too far, but the impact of Western thinking on the destruction of the environment is by no means small. 
Tu Weiming points to the Western Enlightenment mentality as the main culprit in the destruction of the environment. According to him, the Enlightenment mentality underlies the rise of the modern West: science and technology, industrial capitalism, a market economy, democratic polity, mass communication, and professional organizations. Furthermore, liberty, equality, human rights, the dignity of the individual, respect for privacy, government for, by, and of the people, and due process of law are genetically related to the Enlightenment mentality. However, there is a dark side to the modern West as well. The Enlightenment mentality, fuelled by the Faustian drive to explore, know, conquer, and subdue, has persisted as the reigning ideology of the modern West. As such, modern Western hegemonic progress may entail inequality, self-interest, and individual greed ( $\mathrm{Tu}$ 1998, 3-5).

In this sense, Thomas Berry argues that the magnitude of destructive industrial processes is so great that we must initiate a radical rethinking of the myth of progress and of humanity's role in it. He asserts that we have become autistic in our interactions with the natural world because we are locked in our own egocentric perspectives and short-sighted needs (Berry 1988; Tucker and Grim 1998, xvii). The poet Wendell Berry said:

We have lived by the assumption that what was good for us would be good for the world. And this has been based on the even flimsier assumption that we could know with any certainty what was good even for us. We have been wrong. We must change our lives, so that it will be possible to live by the contrary assumption that what is good for the world will be good for us. (Berry in Keenan 2018, 187)

What is now required of mankind is a full and thorough self-reflection and a transition to a completely new awareness. What is ecological nature to us? Do we deserve to own, use, consume and destroy it? Where will we live after ecological nature is destroyed? Unless we change our perception of ecological nature, understand the world anew, and pursue an ecological life, we will never escape the pandemic. Rošker said:

The face of such a crisis, ethical decision-making becomes crucial, because science alone cannot tell us what values we should prioritize. The important decisions in this context are clearly ethical and not scientific. (Rošker 2021, 64)

Her words can also be applied to changing our attitudes towards ecology. We can no longer regard ecology only as object beings and natural resources separate from 
humans and entrust it to Enlightenment science. Ecology must be regarded as an ethical object rather than a scientific object, and it must be treated as an object of ethical practice rather than scientifically explored and developed.

\section{Deep Ecology and Neo-Confucianism}

What is ecology to us? Ecology is concerned with the idea of the Greek oikos, or "house", as in oikumene, "inhabited world". A house is a "dwelling" in a broad sense: an individual, social, and cosmic sense of house is oikos (Ro 1998, 170). In this respect, ecology can be said to be the cradle and dwelling place of mankind, which cannot be separated from human life. If we do not have ecology, we are just homeless wanderers. What kind of epistemological shift is needed to recognize the natural environment as a home for human life rather than a usable resource? What is the metaphysical basis for the shift? Western intellectuals are urging a comprehensive change in the perception of ecology. Various views of environmental ethics on ecology and life have been raised, and the ecological movement is actively developing based on them. Among them, I would like to pay attention to deep ecology. Because it insists on the most radical and thorough shift in perspective on ecology, deep ecology will lead to the most fundamental reflection and transformation for the resolution of the current ecological destruction and pandemic, even if it has some unrealizable aspects.

Lovelock redefines the ontological meaning of ecology. According to him, the Earth itself is a living planet, which he called Gaia. Despite the continued increase in entropy, the Earth has maintained homeostasis for the past 4 billion years, because it is able to maintain its own life in an appropriate equilibrium state, which is evidence that it is a living planet. The Earth itself can be said to be a single complex life form that includes the biosphere, atmosphere, ocean and soil. And humans are only a small species that parasitize life on Earth, and do not have any leading authority. Nevertheless, human beings have harmed the Earth, their mother, with industrialization and urbanization. As such, Lovelock argues, humans are just pests, "intelligent fleas" (see Lovelock 2000). Lovelock uses this view to criticize human activities that degrade and pollute the living planet. Whether intended metaphorically or literally, the Gaia hypothesis is a powerful source of ethical arguments in favour of protecting the natural environment (Desjardins 2013, 170).

Naess also urges us to completely change our perception of ecology. He argues that humankind should no longer perceive ecology shallowly as a resource, but should understand it "deeply" as the basis of mankind and the mother of all life. He sees individual beings as related to each other and belonging to the Earth as 
a huge single life. This is a "a kind of vast whole" created by all beings intertwining with each other through a complex network of relationships, so Naess defines the Earth as a "relational total field" (Naess 1989, 200). He likens individual beings to water droplets and the Earth to an ocean of life, asserting that "all Life is fundamentally one". Individual beings are thus nothing but cells of the vast living organism of nature, including humans (Barnhill 2001).

According to Naess, individual living beings coexist in a relationship with each other on the huge base of life called the Earth. There is no independent thing. To exist is to be related, and without a relationship, there is no existence. In this sense, Naess asserts that no living beings on Earth have a position superior to others, in that all beings are evenly related and coexist. All things are in an absolutely equal relationship. All beings are equal and have equal rights. Such rights are absolute and cannot be violated or deprived by anything, and no one can possess or control any other being (Naess 1995, 223). This can be said to be biotic egalitarianism, and thus Naess argues that human beings have no right to control or use nature at all, but rather that we should be reduced to a smaller population, minimizing interference with the natural world (ibid. 1998, 196-200). His thoughts, needless to say, urge deep reflection on the modern Western worldview, which places humans in a dominant position and ordered to use all other living things in nature (Devall and Sessions 1985, 65-66).

But Naess's argument seems to be insisting that we must give up our identity and status as human beings and return to primitive nature. Is this possible? Here, Naess calls us to a new ethical attitude. This converts human desires into ecological concerns so that we become ecological ethical subjects. He calls this "Self-realization". According to Naess, the modern view of the self takes the individual's selfish desire for granted and regards struggles or agreements with others as legitimate, but we must now abandon this attitude and regard all living beings as ourselves. When we deeply recognize the ecological fact that all living things are closely interwoven within one network, we can abandon our selfish and destructive desire to conquer nature and regard all beings as one body. In other words, the modern "self" must be transformed into an ecological "Self". This Self can be realized through identification between the self and the other. Identification means that we regard other living beings as our own bodies, and either embrace them within ourselves or dwell within them. Through this process, the self is transformed from an egoistic, isolated, and atomic self, to an altruistic, interdependent, and holistic Self. Naess argues that the preservation of biodiversity in nature and the symbiosis of all living beings can be achieved through Self-realization (Naess 1989, 81-85). He describes the state of the ecological great Self-realization through the identification of the self and other as follows: 
Early in life, the social "self" is sufficiently developed that we do not prefer to eat a big cake all by ourselves. We share the cake with our friends and our nearest. We identify with these people sufficiently to see our joy in their joy, and our disappointments in theirs. Now is the time to share with all life on our maltreated Earth through a deepening identification with all life-forms and the greater units: the ecosystems and Gaia, this fabulous old planet of ours. (Naess 2005, 526)

If this is the case, however, how is a Self-realization that identifies the self and the other concretely practiced? Naess defines emotions as crucial in leading us into caring for others, and emphasizes empathy and compassion. He argues that our empathy should reach not only humans but also all living things on Earth, as we have an ethical obligation to care for all beings. He states that he felt compassion when he saw a dying flea in a chemical lab, which originated from a feeling of identification, and stresses that this is the basis of solidarity between human beings and ecosystems (ibid., 518).

Naess's ideas are not unfamiliar in the East. The Chinese philosophy of life and relational ethics overlaps with the claims of deep ecology. For example, Chinese philosophy represents a life-centred cosmology defined by an all-prevailing instinct for life and survival, a holistic worldview predicated upon an organic wholeness, a relational ontology and interpersonal empathy, and Self-realization through the community, among other things (Rošker 2021, 67-71). These ideas are not limited to human society, but can be widely applied to all beings in ecosystem.

Confucianism has significant intellectual and spiritual resources to offer in the emerging discussions regarding attitudes toward nature, the role of people, and environmental ethics. Its dynamic, organismic worldview, its vitalist understanding of $q i$ (氣), its respect for the vast continuity of life, its sense of compassion for suffering, its desire to establish the grounds for just and sustainable societies, its emphasis on holistic, moral education, and its appreciation for the embeddedness of life in interconnected concentric circles, are only some examples of the rich resources of the Confucian tradition in relation to ecological issues (Tucker and Berthrong 1998, xxxv).

In particular, Neo-Confucianists were convinced that all things in the universe were originally one body in terms of metaphysics, and emphasized that benevolence $(\text { ren } \text { 仁 })^{1}$, the ultimate value of Confucianism, means that all beings achieve

1 Kuwako Toshio 桑子敏雄 proposes that in the context of ecology, he will translate ren as benevolence, not humanity or humaneness. This is not because benevolence is a satisfactory translation, but because humanity or humaneness is inappropriate in relation to ecology. The term "humanity in Heaven and Earth" is awkward and contradictory. Kuwako says he will not use the translation of humanity or humaneness to show the anti-anthropocentrism of Neo-Confucianism (Kuwako 1998, 154). Moreover, it may be mistaken for something related to the humanism of the Western tradition. I agree with his idea and translate ren as benevolence in this paper. 
their will to live and become one by interacting with each other smoothly. Cheng Hao 程影 clearly explained the meaning of benevolence by comparing it to a paralyzed body. He said:

The man of ren regards Heaven and Earth and all things as one body. To him there is nothing that is not himself. Since he has recognized all things as himself, can there be any limit to his benevolence? As in the case of paralysis of the four limbs, the vital force no longer penetrates them, and therefore they are no longer parts of the self. (Cheng Hao in Chan 1963, 530)

According to the metaphysics of Neo-Confucianism, the essential state of the self is oneness with all things, and the purpose of cultivation is to identify all things with the self. In this sense, Self-realization constitutes a great Self that encompasses all things within itself. Zhang Zai 張載 regarded Heaven and Earth and all beings as one family and one body in Ximing 西銘 (The Western Inscription), and asserted Self-realization in "enlarging the mind" (daxin 大心). He says:

By enlarging one's mind, one can enter into all the things in the world. If anything is not yet entered into, there is still something outside the mind. The mind of ordinary people is limited to the narrowness of what is seen and what is heard. The sage, however, fully develops his nature and does not allow what is seen or heard to fetter his mind. He regards everything in the world to be his own self. (Chan 1963, 513)

His argument can be said to be consistent with Naess's concept of Self-realization. Furthermore, it is also in line with Naess's idea that Neo-Confucianists emphasize empathy in the process of identification. According to Neo-Confucian thinking, since all living beings were created by Heaven, they all have a will to live equally and a noble right to live their own lives well. Therefore, Neo-Confucianists seek to realize the will of Heaven by helping the lives of all things without infringing upon them. Empathy is the impulse that puts them into practice. It is the same as Mencius's "the mind which cannot bear to see the suffering of others" (burenzbixin 不忍之心) and is mainly expressed as compassion for the weak. For example, Zhou Dunyi 周敦匵 did not cut the grass growing outside his window, because he thought the feeling of the grass and his mind were the same. Zhang Zai heard the cry of a donkey and said the same thing (Cheng and Cheng 1981, 60). ${ }^{2}$ And Cheng Yi 程頣 rebuked the young emperor for breaking branches on spring days,

2 周茂叔窗前草不除去. 問之, 云與自家意思一般.子厚觀驢鳴,亦謂如此. 
saying that "You must not break branches without any reason" (ibid., 342). ${ }^{3}$ Wang Yangming 王陽明 is perhaps the most vivid example of empathy and Self-realization. He felt compassion for weak animals as well as inanimate objects (tiles and stones shattered and crushed) and identified with them. Wang emphasizes that seeing all things as one's own body is Self-realization, and that such a person is a great man (daren 大人) and benevolent man (renzhe 仁者). ${ }^{4}$ All of these examples can today be reinterpreted as the ecological attitude.

We need not accuse these earlier thinkers of unscientific animism. They were not unscientific, but ethical. The reason Neo-Confucianists felt compassion for trivial animals, grass, and even broken tiles was not because they believed that spirits reside in these things, but because they wanted to treat these things with a moral mind. A view of the world cannot and should not be solely scientific. In today's ecological crisis, as Rošker noted, important decisions are clearly ethical and not scientific.

Deep ecology and Neo-Confucianism are similar in many ways. Both Naess and Neo-Confucianism emphasize that we should identify with both the self and other, and should feel compassion and empathy for the other, and further stress that Self-realization and cosmic solidarity can be achieved when those feelings are expanded to infinity. In short, the ecology of Naess and Neo-Confucianism will enable eco-ethical practice of caring for all living beings in the ecosystem, as well as mitigating the harmful effects of indiscriminately taking resources and destroying nature.

However, it should not be overlooked that there are some clear differences between them. Deep ecology is by no means perfect, and has been criticized in many ways. For example, biotic egalitarianism is criticized for denigrating human's status in the natural world and negating the value of cultural human beings. This is not found in Neo-Confucianism, which instead focuses on the role of human beings as ecological subjects. Humans are the helpers of the ecology that help all beings to live well. Neo-Confucianism did not believe that nature and humans were separated or opposed in the first place, but that human efforts further enlarged the sphere of life of ecological nature and strengthened its vitality. On the other hand, Naess still did not get out of the Enlightenment frame of mind that humans and nature are opposed to each other, so he thought that the realm of humans should be reduced for the sake of ecology. This is unacceptable in Neo-Confucianism. As discussed in detail later, Neo-Confucianism emphasizes the necessity of human beings as practitioners of ecological well-being. This is the main difference between deep ecology and Neo-Confucianism.

3 一日講罷未退, 上忽起, 憑檻戲析桝枝. 先生進曰: 方春發生, 不可無故摧折. 上不悅.

4 See, Wang Yangming, Daxuewen 大學問 (Inquiry on the Great Learning) (Chan 1963, 659). 
Furthermore, Naess's method of ecological practice is not perfect. Empathy and identification are very important in that they are the motives and driving forces of ethical practice, but these alone cannot be a complete and successful practice. Empathy tends to be ambiguous, capricious, and arbitrary. In addition, it is possible to mis-empathize with the other's situation, and the empathizer may treat the other unilaterally the way he feels. How can we be sure that human empathy about other living things is always correct, and that human behaviour will be always performed in the right way? If people's empathy and behaviour are wrong, their concerns and treatment will result in destroying nature, and the bad consequences will affect humans again.

In this respect, empathy must be objective and reasonable, and for these humans must become appropriate empathizers. To this end, Neo-Confucianism emphasizes the necessity of self-cultivation and suggests two methods. The first is internal cultivation, which is to maintain reverence (jujing 居敬) that makes the mind of the empathizer impartial without selfishness. Keenan sheds light on the ecological significance of maintaining reverence. According to him, one can achieve a form of personal identification with other living things through this practice (Keenan 2018, 199), because reverence clarifies the human mind without selfish desire and unifies it with the principles of Heaven, and so the empathizer can form one body with all things without self-centred bias. In this sense, the ChengZhu School (程朱學派) placed great importance on maintaining reverence. The second method is external cultivation, which is to investigate things (gewu 格 物), as this makes the empathizer understand the other correctly and treat them appropriately. Each being wants to live in their own way of life, but if the empathizer treats them according to his or her own feelings without an accurate understanding of their nature and situation, this can lead to unnecessary interference or even violence. And the result will again affect human beings. Therefore, the investigation of things is essential for appropriate empathy and moral practice, and this will be explained in detail later (see, chap. "Investigation of Things and Self-Realization").

\section{The Mission of Humans: Realization of Ecological Justice}

Naess sought to demote the status of human being as rulers of the ecology. He thought that the ecology would recover to its optimum state only when people ceased to invade and dominate it and come down to an equal position with other beings. But Zhu did not think so. He stressed the active practice of human beings realizing the will of Heaven and Earth. Since Heaven and Earth have the will to 
give birth to and grow all things, human beings must help them to realize that will to the fullest. In short, the mission of humans is "to participate and assist in the transforming and nourishing process of Heaven and Earth" (canzanbuayu 參 贊化育).

But what does it mean to participate and assist in this? Cheng Yi explained that people simply conform to the laws of nature with an attitude of sincerity (cheng 誠), but not actually assisting Heaven and Earth (Cheng and Cheng 2002, vol. 11)..$^{5}$ According to him, there is nothing humans have to do for the prosperity of all things, and there is no important position of humans in the ecosystem. Humans are merely bystanders of nature. Zhu, however, opposes his idea.

Zhongyong 中庸 (The Doctrine of the Mean) states "The sage assists in the transforming and nourishing process of Heaven and Earth." Human beings are located between Heaven and Earth, although the trinity serve the same purpose, they have different tasks. There are things that human beings can do, but Heaven and Earth cannot do in the transforming and nourishing process. For example, Heaven gives birth to all things, but ploughing and sowing the fields require human effort. Water can moisten all things, but irrigation must be done using human power. Fire can burn all things, but making a fire with firewood must use human power. "Controlling all things and complementing each other” (caichengfuxiang 財成 輔相) is something that human beings must do. What about this is not assisting Heaven and Earth? Master Cheng said, "It is not actually assisting Heaven and Earth", and that it is actually wrong. (Zhu 1986, vol. 64) ${ }^{6}$

While the role of Heaven and Earth is to give birth to and make all things live, the role of human beings is to help the living beings fully realize their will to live. With the help of people, all living beings can become more satisfied and prosperous. The flourishing of all things is the original will of Heaven and Earth, but it cannot be achieved alone. For this reason, humans must help Heaven and Earth to realize and expand their will. From this point of view, the status and role of human beings are very important in Zhu's ecological cosmology, as they are nurturers who look after and care for the creatures of the ecosystem on behalf of Heaven and Earth.

5 至誠可以贊天地之化育, 則可以與天地參贊者. 參贊之義, 先天而天弗違, 後天而奉天時之 謂也. 非謂贊助, 只有一䇢誠何助之有.

6 “贊天地之化育.” 人在天地中間, 雖只是一理, 然天人所爲, 各自有分, 人做得底, 卻有天

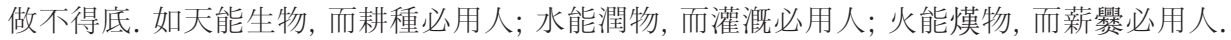
裁成輔相, 須是人做, 非贊助而何? 程先生言：““參贊”之義, 非謂贊助.” 此說非是. 
Zhu's thoughts, however, should not be mistaken for anthropocentrism. The fact that he emphasized the role of human beings does not mean that he defined them as owners and users of all things. The role of people is only to help all things live contentedly, not to exploit and destroy them. While Naess argues that for the purpose of restoring optimal ecology people must be driven out of the centre of ecology, Zhu argues that human action is necessary for this purpose. Zhu's anthropology is markedly different from the anthropocentrism of the West.

Furthermore, Zhu emphasizes that the existential purpose and ethical obligation of human beings are the flourishing of the entire ecosystem. Human beings can fulfil their purpose of existence only when they faithfully realize the will of Heaven and Earth, which is nothing other than achieving the flourishing and satisfaction of all beings in the ecosystem. Zhongyong said: "Sincerity is not only the completion of one's own self, it is that by which all things are completed" (Chan 1963, 108). In this sense, the Self-realization must imply the realization of the other. As Zhu says:

To fully realize another person's life (jinren 盡人) is to treat each person appropriately, whether virtuous or mean, whether dying young or living long, so that every being can acquire an optimal abode (gedeqisuo 各得其 所). To fully realize another being's life is to treat each being appropriately, regardless of being a bird, animal, insect, fish, grass, or tree, so that every being can live an optimal life (gedeqiyi 各得其宜). (Zhu 1986, vol. 64) $)^{7}$

Zhu's words have several implications. The first is biotic egalitarianism. As creatures of Heaven and Earth, all beings have an equal right to live their lives satisfactorily. Second, however, is the diversity of lives. All beings live their own way of life, and each way must be respected. Third, human beings are responsible for all of them. The human duty is to help all beings live optimal lives because humans are the surrogate nurturers of Heaven and Earth. Fourth, human beings should know the patterns of each being's life in detail and treat each one appropriately. For this, Zhu says that people should investigate the principles of each being's life (qiongjiqili 窮極其理), and should help them to fully realize their lives in accordance with those principles (jinqili 盡其理). In short, Zhu argues for biotic egalitarianism similar to Naess. However, unlike Naess he emphasizes the role and duty of human beings as well as the diversity of beings, then argues that the role of humans is to observe the differences of all beings and treat them accordingly.

7 至於盡人, 則凡或仁或鄙, 或夭或壽, 皆有以處之, 使之各得其所. 至於盡物, 則鳥獸蟲魚, 草 木動植, 皆有以處之, 使之各得其宜. 
It would be an ideal state not only for human society but also for the entire ecosystem that all beings lived their lives happily without interference. This is an appropriate ( $y i$ 宜) and harmonious (he 和) state. Xunzi 荀子 believed that such a state could be realized through righteousness ( $y i$ 義). He emphasized that because there is righteousness in mankind, society is constituted, and all living beings, including human beings as well as animals and plants, can live lives worthy of their true natures, in the ideal state of "happy symmetry" (Ivanhoe 1991). ${ }^{8}$

According to Chen Lai 陳來, the word righteousness (義) has two meanings. One is "appropriateness" (宜) and the other is "to restrict" or "to judge" (Chen 2020). In short, the word righteousness (義) means a comfortable and appropriate state (宜), and at the same time it also means the determination and restrictions needed to achieve that state. As Zhu says, "righteousness is the determination of the mind and the appropriateness of the situation" (Zhu 2003, 201). ${ }^{9}$ But what is the appropriateness of the situation? Zhu explains it with a "measuring square” (xieju, 絜矩):

If a superior wants to take care of his family (xiaodi 孝弟), then of course, subordinates also want to take care of their family. The superior must ensure their survival so that the subordinates can satisfy themselves the need to care for the family. So, it can be called the Way of the measuring square. If, against their conscience, they voluntarily collect heavy taxes and extort the people's property, so that they cannot fulfil their desire to take care of their own families, that is injustice. (Zhu 1986, vol. 16) ${ }^{10}$

Daxue 大學 (The Great Learning) presents the Way of the measuring square as the method to make the world peaceful (pingtianxia 平天下). Zhu interprets "to make peace" (ping 平) as “to make equal" (junping 均平) (Zhu 1986, vol. 16). ${ }^{11}$ According to Zhu, the way to make the world peaceful begins with equal distribution of resources to ensure the all beings can survive. He argues that all human beings should be able to equally satisfy their family's survival needs regardless of their position, and that superiors must satisfy the people's needs. This is because it is a basic need for survival that cannot be violated. In the desire to live life in a family community, there can be no discrimination between upper and lower

8 According to Ivanhoe (1991), Xunzi is similar to Hobbes, but unlike Hobbes, Xunzi opposed human's reckless development of nature and tried to achieve a happy symmetry with ecosystems.

9 義者, 心之制·事之宜也.

10 上面人朁自有孝弟, 下面民亦有孝弟, 只要使之自遂其孝弟之心於其下, 便是絜矩. 若拂其 良心, 重賦橫斂以取之, 使他不得自遂其心, 便是不方.

11 平天下, 謂均本也. 
status. For Zhu, social justice is a condition in which everyone can enjoy their own life with equal guarantees of survival. This state is appropriate, and is the situation in which righteousness is realized.

Confucianism always regards righteousness and interest as antagonistic, and warns that interest harms righteousness and harmony. But this is a misunderstanding. The interests that Confucians warned of were taking excessive profits beyond the fair portion, and the legitimate interests necessary for survival were perceived as righteous and harmonious. In other words, the fair share that individuals must have for a humane life must be satisfied, and this will then achieve a harmonious society, as Zhu emphasizes:

Zhouyi 周易 (The Book of Change) said "Benefiting creatures, the superior man is fit to exhibit the harmony of all that is right (利物足以和義)”. This means that there will be no disharmony in its righteousness if all beings can all benefit from it. Righteousness means limiting and cutting, so it can be seen as harming harmony. But only righteousness allows all things to be proper in each other, not to interfere with each other, and not to infringe on one another, so that all beings gain their share and harmonize. (Zhu 1986, vol. 68) $)^{12}$

Zhu believed that harmony in society could be realized only when all beings could fully enjoy their own appropriate interests. To do this, we need a righteousness that protects the proper share of all. It can be said that righteousness is the basis for distributing profits fairly and creating harmony in society, and thus Zhu asserts "there is no justice unless it benefits all beings" (Zhu 1986, vol. 6). ${ }^{13}$

Zhu's concept of righteousness can be applied to elucidate ecological justice. The ideal state of ecology can be said to be a "happy symmetry" in which all beings are in joyful harmony while living their own lives contentedly without interference. This can be defined as a state of ecological justice. Perhaps anthropocentrists would ask: Do all things in nature have the right to live their lives satisfactorily? Where does that right come from? They would argue that if all things did not have such a right, there would be no ecological justice. To this, Zhu would answer that the right to life in all things is equally acquired from Heaven and Earth, the survival of all things is the will of Heaven and Earth, and ecological justice is to achieve happy symmetry in the natural world while all beings live their lives

12 利物足以和義者, 使物物各得其利, 則義無不和. 蓋義是斷制裁割底物, 若似不和. 然惟義能 使事物各得其宜, 不相妨害, 自無乘戻, 而各得其分之和.

13 利物足以和義, 義者, 事之宜也; 利物, 則合乎事之宜矣. 此句乃翻轉, 義字愈明白, 不利物則 非義矣. 
satisfactorily. Zhu said, "The mind of Heaven and Earth is to produce things. In the production of man and things, they receive the mind of Heaven and Earth as their mind" (Chan 1963, 593). ${ }^{14}$ According to Zhu, the mind of Heaven and Earth is the will of life, and the minds of man and things are also the same will of life as the mind of Heaven and Earth. The mind and will of all beings can be interpreted as an inviolable right. Therefore, all things can fully achieve their own life. They must not infringe upon the lives of other beings, nor are they infringed upon by other beings. When every being fully achieves their own life, the life of Heaven and Earth can be achieved. This state can be called ecological justice and benevolence. In this respect, Zhu said "Righteousness is appropriateness, and appropriateness is righteousness. It is the sum of righteousness that all things have their own abodes to live appropriately." (Zhu 1986, vol. 68) ${ }^{15}$

Therefore, the mission of humans as ecological subjects is to provide the help and care needed for all beings to live their lives well, and thus fulfil the will of Heaven and Earth. In order to meet human desires and needs, humans should not interfere with other lives recklessly, but rather watch over and protect them.

When the sage appeared in the world and took care of all beings, he guided their lives according to their own nature. So, none of the creatures, such as insects and plants, did not live according to their nature. People obtained them at the right time and used them according to the rules. At the time of birth in the spring, young pups were not caught, nests were not spilled, and embryos were not killed. After the vegetation was gone, the sage allowed people to go into the mountains to get firewood, after the otters performed ancestral rites with fish, allowed the hunters to go into the lakes, and after the wolves commemorated forebears with animals, ${ }^{16}$ allowed to hunt. In this way, the reason that the sage enabled all creatures to live their optimal lives is because he knew in advance the original will of Heaven and Earth to bear and grow all beings. (Zhu 1986, vol. 114) $)^{17}$

Zhu's words show his reverent and cautious attitude towards ecology. He introduces the ecological behaviour of the sage as the ideal human, and tells us the ecological norms of how we should behave. The sage understands the lifestyles of

14 天地以生物爲心者也. 而人物之生, 又各得夫天地之心以爲心者也. Renshuo 仁說 (A Treatise on Benerolence).

15 義者, 宜也, 宜郎義也; 萬物各得其所, 義之合也.

16 An otter's behavior indicates the end of winter (January on lunar calendar), and a wolf's behavior the onset of winter (from October on) (see Kong Yingda 1999, 6: 375).

17 聖賢出來掹臨萬物, 各因其性而導之. 如昆蟲草木, 未嘗不順其性, 如取之以時, 用之有節: 當春生時 ‘不殀天, 不覆巢, 不殺胎; 草木零落, 然後入山林; 獺祭魚, 然後虞人入澤梁; 豹 祭獸, 然後田獵”. 所以能使萬物各得其所者, 惟是先知得天地本來生生之意. 
all beings in nature and helps them live according to this. He fully respects their lives, minimizing encroachment on their ecological areas, even when people need resources. That way, every living being can enjoy their life equally. There is no discrimination of classes, races, or species. All beings are equally respected and related to each other. This egalitarian ecological network would be the image of ecological justice that Zhu imagined.

\section{Investigation of Things and Self-Realization}

Naess argues that the attitude toward all objects in the ecological world is the identification between the self and them. For Naess, such identification is perceived as an emotional and aesthetic act rather than an ethically normative one. However, this has a weakness in that it is difficult to secure objectivity and validity in practice. For ecological practice, an intuitive and emotional awareness to realize the wholeness of ecology (like Naess does) is required, but concrete actions to realize that intuitive awareness in the real world are also needed. In other words, it is necessary to explore concrete and realistic ecological sites as well as to understand the wholeness and integrity of lives, because the way various being exist in the real world is different. If one does not investigate them concretely, such an ecology will remain an abstract and vague idea, and its practice in the real world will be blurred. We can consider this issue based on Zhu's theory of "principle is one but manifestations are many" (liyifenshu 理一分殊).

All things have this principle, and the principle comes from one source. However, since the circumstances in which each being lives are different, the functions (yong 用) of the principle are different.... (and conversely) All beings each have their own principles and live in different ways, but there is nothing that is not the activity of a single principle in their lives. The sage "explores the principles of all beings and realizes their own natures so that they can reach heaven's mandate" (窮理盡性而至於命). Therefore, the sage explores all the principles of all beings in the world to the very end, so that they can each find their own place to live satisfactorily and arranges even the smallest thing to achieve the optimal state. If there is no thing, there is no principle of it. If there is a thing, there is nothing that a sage does not fully realize of it. Thus, Zhongyong said, "If they can assist in the transforming and nourishing process of Heaven and Earth, they can thus form a trinity with Heaven and Earth." (Zhu 1986, vol. 18) $)^{18}$

18 萬物皆有此理, 理皆同出一原. 但所居之位不同, 則其理之用不一........物物各具此理, 而物 物各異其用，然莫非一理之流行也. 聖人所以 “窎理盡性而至於命”，凡世間所有之物，莫 
This is an important logic of Neo-Confucian metaphysics that elucidates the relationships between universal and particular, unity and diversity, ultimate idea and concrete norms. In response to Yang Shi's 楊時 question, Cheng Yi 程頤 emphasized that universal moral principles can be expressed in different concrete norms, and that different concrete norms contain universal moral principles. However, Cheng emphasized that benevolence (仁) as a universal moral principle can only be realized by practicing righteousness as a concrete norm of practice (Cheng and Cheng 2001, vol. 9). ${ }^{19}$ It was not a deductive practice method that applied a single universal principle to various things, but an inductive method that grasped the universal moral principle in the process of practicing various concrete norms one by one. In other words, while the "one principle" is only a metaphysical premise or ultimate goal, the cultivation and practice to realize it should proceed only in "many manifestations".

Zhu inherited Cheng's thought and made it the basic structure of his own worldview. This applies to his ecological point of view as well. Although the original life of Heaven and Earth is one, that original life is revealed by the lives of numerous beings. Thus, all life is the same and different, different and the same. However, ecological practice consists in carefully examining and caring for various beings, not contemplating the original life of Heaven and Earth. It is necessary to take concrete actions to care for and help various individual beings to live contentedly according to their own way of life, and the original life substance can be realized through the accumulation of those actions. In other words, canzanbuayu (參贊 化育) is nothing but the practice of righteousness to assist and arrange even the smallest thing to achieve the optimal state. Only when ecological righteousness is practiced can cosmic benevolence be realized.

In this regard, Zhu emphasizes the investigation of things (gewu 格物). In general, gewu is defined as exploring the objects in the world and understanding their principles. The purpose of the traditional "investigation of principles" was ultimately the task of understanding one's complex relational reality and the conduct fitting such a reality, but beyond such traditional concerns a postmodern investigation of principles would direct itself not only to the pattern of human social relatedness, but also to its embeddedness in the larger network of life and Earth relationships as well. The simple facts that bear on our relational reality and the temporal rates of natural processes call for equally deep reflection and have the power to transform our lives profoundly (Kalton 1998, 97). Gewu

不窮極其理, 所以處置得物物各得其所, 無一事一物不得其宜. 除是無此物, 方無此理; 睡有 此物, 聖人無有不盡其理者. 所謂 “惟至誠贊天地之化育, 則可與天地參者也.

In “Letter in Reply to Yang Shi's Letter on the Western Inscription (答楊時論西銘書)”. 
is also scientific, but this is very different from the modern Western, scientific attitude. Because even science is a symbol of the sentiments of life (Rošker 2021, 67), and its purpose is not to pursue intellectual satisfaction, but to love all beings (aiwu 愛物). The ultimate purpose of this is to realize benevolence as the ultimate value. Meng Peiyuan 蒙培元 defines gerwu as deep ecology (Meng 2010), and this is quite reasonable.

Since the ancients loved all beings in the nature, they also set a time for cutting down a tree. Since there was no place where their love did not reach even the slightest bit, there was no being which did not benefit from it. the ancients were able to do this because they thoroughly practiced gerwu. (Zhu 1986, vol. 15) ${ }^{20}$

Zhu's gewu is an effort to understand the ecological principles and ways of survival of other beings in order to better consider them in the ecosystem. It is to thoroughly explore the principles of each being and lead the lives of all things to their optimal state. Compassion and empathy are important, but they alone cannot provide adequate consideration for all beings. Only when we investigate closely the lifestyles of living beings in the ecosystems we can treat them appropriately. This attitude seems to be in line with A. Weston's "environmental etiquette". Proposing "multicentrism" (Weston 2004, 30-36), he argues that humans should regard all beings in the ecosystem as the centre of the universe and engage in equal communication with them. According to Weston, people should carefully observe and kindly care for all living things and help them to fully realize their lives. This is the "etiquette" of human being towards ecology, and in this way people can communicate with other beings and participate in the life of the Earth together (ibid., 37-38). Needless to say, Zhu's metaphysics is a kind of centrism, but his attitude towards all beings seems to be close to multicentrism. According to his theory of liyifenshu (理一分殊), the world fundamentally converges to one principle, but in the phenomenal world it is revealed by the lives of various beings. Each of these beings has the right to live their life well, and humans have a duty to protect their rights. This is because people are a being of the Trinity with Heaven and Earth, and they regard canzanbuayu as their moral duty. It is the moral responsibility that is bestowed upon humankind as the highest embodiment of the moral content of the universe that draws the unique Confucian position on the relation of humankind and the universe (Taylor 1998, 43). Gewu is nothing more than a way to protect and realize the rights of all beings.

20 古人愛物, 而伐木亦有時, 無一些子不到處, 無一物不被其澤. 蓋緣是格物得盡, 所以如此. 
Zhu asserts that by clearly understanding other beings we can deeply empathize with them, and by caring for them kindly, we can reach a point where the subject and the object are united.

The self and the other have never been separated. If we know that the principle of life of beings is like this and treat them according to their natural principles, then we will understand the principle of the unity of the self and the other. All beings in sight now have their own principles of life. Every grass, every tree, every bird, every beast has a principle of life. Grass and trees are born in spring and wither in autumn, want to live and hate to die. We are well aware that all things have the same energy and the same body as us, therefore (Mencius said) "having seen them alive, he cannot bear to see them die; having heard their dying cries, he cannot bear to eat their flesh", "Do not cut down a tree or kill a small beast unless the time is appropriate", and (Liji 禮記 said) “They did not kill pregnant animals, nor those which had not attained to their full growth. They did not throw down nests." This is the principle of the unity of the self and the other. (Zhu 1986, vol. 15) ${ }^{21}$

One of the important methods of gerwu is inference (tuile $i$ 推類). Inference is a method of cognition that grasps the unknown based on what is known and understands the distant based on what is close. This includes the extension of empathy as well as logical reasoning. Zhu emphasizes the need to expand empathy by recognizing that all beings have the same life needs and principles as ourselves. This is the same as Confucius said, "to be able to judge of others by what is nigh in ourselves (nengjinqupi 能近取譬)”. Therefore, gewu does not stop with the search for knowledge, but creates empathy based on that knowledge to feel and care for beings as if they were ourselves. When we fully satisfy the life needs of beings in this way, we become one with them. And if we continue to practice this process, we will eventually reach the point of fully understanding the essence and principle of all beings in the world (buoranguantong 豁然貫通). Only then can we experience the ultimate unity (wanwuyiti 萬物一體) that fuses nature into us and dissolves us into nature. This is the Self-realization pursued by Zhu, which is the identification and achievement of the great Self, as it were, when the self is expanded to include all beings within the self, while the self resides in all beings.

21 他內外未嘗不合. 自家知得物之理如此, 則因其理之自然而應之, 便見合內外之理. 目前事 事物物, 皆有至理。如一草一木, 一禽一獸, 皆有理。草木春生秋殺, 好生惡死。“仲夏斬陽 木, 仲冬斬陰木”, 皆是順陰陽道理. 自家知得萬物均氣同體, “見生不忍見死, 聞聲不忍食 肉”, 非其時不伐一木, 不殺一獸, ‘不殺胎, 不殀夭, 不覆巢” , 此便是合內外之理. 


\section{Conclusion}

COVID-19 has brought major changes to society and is encouraging mankind to fundamentally reflect. It has made us rethink why we need civil autonomy and community solidarity. To ensure the safety of individuals and communities, human relationships must now change, education systems, political structures, economic relations, and cultural production must all change as well. However, it will not be easy to cope with the outbreak of fatal viruses just by changing the structure of society. What is more fundamental is that the ecological perception needs to be changed. Clearly, the pandemic is caused by human intervention and destruction of ecology. Without clear awareness of this fact, thorough reflection, and change of perception, a pandemic like COVID-19 will keep happening.

In this paper, in order to urge a fundamental change in the perception of ecology, the practice of ecological justice was considered based on Zhu's philosophy. While agreeing with the transition to ecosophy suggested by Naess, it was argued in this article that the establishment of ecological justice is necessary in terms of practice. Naess's deep ecology has great significance in that it presents an eco-centred worldview while reflecting on the ills of technology and dismantling anthropocentric thinking. Based on the holistic life theory and biotic egalitarianism, he acknowledges the equal value of life for all beings in the ecosystem and tries to prevent humans from selfishly encroaching on nature. He also insists on Self-realization, in which humans escape from the egoistic self, embrace all beings in themselves, and coexist with all living things. This is to transform human beings from technological capitalist subjects to natural ecological subjects, and it is judged to have significance in evoking a fundamental change in the awareness of people and nature, and awakening human moral responsibility and ecological obligations.

However, Naess's argument has several weaknesses. To address these and realize mutual flourishing with ecology, it is necessary to practice ecological justice. This paper looked for ideas about how to achieve this in the Zhu's philosophy, and paper argued as follows based on this: In order to solve the situation in which the inequality of capitalism is prevalent in the entire ecosystem, measures to protect the basic rights of all beings are required. Ecological justice presupposes that the lives of all beings are equal, and thus protects and helps other beings to live their own lives well. This can be said to be the principle of ecological distribution that respects different lifestyles and takes measures so that everyone can fully enjoy their own lives. When ecological justice is realized, the entire ecosystem will be harmonized, and the Self-realization will become possible. 


\section{Acknowledgement}

The research work for this article was supported by Hankuk University of Foreign Studies Research Fund (2021).

\section{References}

Barnhill, David. 2001. "Relational Holism: Huayan Buddhism and Deep Ecology." In Deep Ecology and World Religion, edited by David Barnhil, and Roger Gottlieb, 77-106. New York: SUNY Press.

Berry, Thomas. 1988. The Dream of the Earth. San Francisco: Sierra Club Books.

Chan, Wing-tsit. 1963. A Source Book in Chinese Philosophy. Princeton: Princeton University Press.

Chase, Steve, ed. 1991. Defending the Earth: A Dialogue between Murray Bookchin and Dave Foreman. Boston: South End Press.

Chen, Lai 陳來. 2020. “Lun gudian ruxuezhong yi gainian 論古典儒學中“義”概 念 (Discussion of the Concept of Justice in Ancient Confucianism).” Wen Shi Zhe (文史哲) 381: 5-21.

Cheng, Hao 程影, and Cheng Yi 程頣. 1981. ErChengji 二程集 (The Complete Works of Master Two Cheng). Beijing: Zhonghua Shuju.

Choi, Jaecheon 최재천. 2020. "Saengtae wa Ingan 생태와 인간 (Ecology and Human).” In Corona Sapiens 코로나사피엔스, edited by Jeong Gwan-gyong 정 관용, 14-43. Seoul: Influential.

Desjardin, Joseph R. 2013. Environmentchanal Ethics: An Introduction to Environmental Philosophy, 5th edition. Belmont: Thomson Wadsworth.

Devall, Bill, and George Sessions. 1985. Deep Ecology. Salt Lake City: Peregrine Smith Books.

Ha, Seungwoo 하승우.2020. "Covid19 Pandemic ihueui sarm gwa saetaesahoijueui 코로나19 팬데믹 이후의 삶과 생태사회주의 (Our Lives after COVID-19 Pandemic, and Eco-Socialism)." Munhak grwa grwahak 103: 97-116.

Hong, Wok-sik. 2011. "Confucianism, Korean Confucianism, and Ecological Discourse.” Acta Koreana 14 (2): 15-40.

Humber, Lee. 2020. "What makes a disease go viral?" Socialist Review 455 (March 2020). Accessed September 15, 2021. https://socialistreview.org.uk/455/ what-makes-disease-go-viral.

Im, Shinjae 임신재. 2006. Dongmul haengdonghak 동물행동학 (Animal Etholo$g y)$. Seoul: Sallim.

Ivanhoe, Philip J. 1991. “A Happy Symmetry: Xunzi's Ethical Thought.” Journal of the American Academy of Religion 59 (2): 309-22. 
Jeong, Seokchan 정석찬. 2020, "Hana eui geongang, hana eui segye: Gihubyeonhwa wa insugongtong gamyeombyeong 하나의 건강, 하나의 세계: 기 후변화와 인수공통감염병 (One Heath and One World: Climate Change and Zoonosis)." In Postcorona Sahoi 포스트코로나사회 (Postcorona Society), edited by Kim Suryeon 김수련, 205-23. Seoul: Geulhangari.

Kalton, Michael C. 1998. "Extending the Neo Confucian Tradition: Question and Reconceptualization for the Twenty-First Century." In Confucianism and Ecology: The Interrelation of Heaven, Earth, and Humans, edited by Mary Evelyn Tucker, and John Berthrong, 77-101. Massachusetts: Center for the Study of World Religions.

Keenan, Barry C. 2018. "Reverence and Cheng-Zhu Ecology." ReserchGate, June 27, 2018. 17:187-201. https://doi.org/10.1007/s11712-018-9600-3.

Kim, Changyeop 김창엽. 2020. “Sahoijeokin geoteuroseo COVID-19: Gwahakgwa Jeongchi saieseo 사회적인 것으로서 코로나: 과학과 정치 사이에 서 (COVD-19 as Social Thing: Between Science and Politics).” In Postcorona Saboi 포스트코로나사회 (Postcorona Society), edited by Kim Suryeon 김수 련, 107-25. Seoul: Geulhangari.

Kong, Yingda 孔穎達. 1999. “Liji Zhengyi 禮記正義 (The Correct Meanings of The Book Rites).” In Shisanjing Zhushu 十三經注疏 (Thirteen Classics Explanatory Notes and Commentaries), edited by Li Xueqin李學勤, vol. 6. Beijing: Beijing Daxue Chubanshe.

Kuwako, Toshio. 1998. "The Philosophy of Environmental Correlation in Chu Hsi." In Confucianism and Ecology: The Interrelation of Heaven, Earth, and Humans, edited by Mary Evelyn Tucker, and John Berthrong, 151-68. Massachusetts: Center for the Study of World Religions.

Lovelock, James. 2000. Gaia: A New Look at Life on Earth. Oxford: Oxford University Press.

Meng, Peiyuan 蒙培元. 2010. "Hewei gewu? Weihe gewu? 何爲格物? 爲何格物? ——從格物說看朱喜哲學生態觀 (What and for What is 'Studying the $\mathrm{Na}$ ture of Things?' — The Eco-philosophic View of Zhu Xi upon 'Studying the Nature of Things').” Quanzhou Shifan Xueyuanbao 泉州師範學院報 28: 1-5.

Naess, Arne.1989. Ecology, Community and Lifestyle. Cambridge: Cambridge University Press.

- 1995. "Equality, Sameness, and Rights." In Deep Ecology for the 21st Century, edited by George Sessions, 222-24. Boston: Shambhala Publication.

- 1998. "The Deep Ecological Movement: Some Philosophical Aspects." In Environmental Philosophy: From Animal Right to Radical Ecology, edited by Michael E. Zimmerman, 193-211. New Jersey: Prentice Hall. 
2005. "Self-Realization: An Ecological Approach to Being in the World." In The Selected Works of Arne Naess, edited by Harold Glasser, and Alan Drengson, vol. X, 515-30. Dordrecht: Springer.

Quammen, David. 2012. Spillover: Animal Infections and the Next Human Pandemic. New York: W. W. Norton \& Company.

Ro, Young-chan. 1998. "Ecological Implication of Yi Yulgok's Cosmology." In Confucianism and Ecology: The Interrelation of Heaven, Earth, and Humans, edited by Mary Evelyn Tucker, and John Berthrong, 169-86. Massachusetts: Center for the Study of World Religions.

Rošker, Jana S. 2021. "Chinese Philosophy of Life, Relational Ethics and the COVID-19 Pandemic.” Asian Philosophy 31 (1): 64-77. https://doi.org/10.1 080/09552367.2020.1863624.

Taylor, Rodney L. 1998. "Companionship with the World, Roots and Branches of a Confucian Ecology." In Confucianism and Ecology: The Interrelation of Heaven, Earth, and Humans, edited by Mary Evelyn Tucker, and John Berthrong, 37-58. Massachusetts: Center for the Study of World Religions.

Tu, Weiming. 1998. "Beyond the Enlightenment Mentality." In Confucianism and Ecology: The Interrelation of Heaven, Earth, and Humans, edited by Mary Evelyn Tucker, and John Berthrong, 3-21. Massachusetts: Center for the Study of World Religions.

Tucker, Mary Evelyn, and John Berthlong. 1998. "Introduction: Setting the Context." In Confucianism and Ecology: The Interrelation of Heaven, Earth, and Humans, edited by Mary Evelyn Tucker, and John Berthrong, xxxv-xlv. Massachusetts: Center for the Study of World Religions.

Tucker, Mary Evelyn, and John Grim. 1998. “Series Foreword.” In Confucianism and Ecology: The Interrelation of Heaven, Earth, and Humans, edited by Mary Evelyn Tucker, and John Berthrong, xv-xxxi. Massachusetts: Center for the Study of World Religions.

UNEP (UN Environmental Programme). 2020. "Six Nature Facts Related Coronaviruses.” UNEP, April 8, 2020. Accessed September 2, 2021. https://www. unep.org/news-and-stories/story/six-nature-facts-related-coronaviruses.

Wang, Shouren 王守仁. 2010. Wang Yangming Quanshu 王陽明全書 (The Complete Works of Wang Yangming). Taipei: Zhengzhong shuju.

Weston, Anthony. 2004. "Multicentrism: A Manifesto." Environmental Ethics 26 (1): 25-40.

White, Lynn. 1967. "The Historical Roots of Our Ecological Crisis." Science 155: 1203-07.

Wing-chit, Chan 陳榮捷. 1963. A Source Book of Chinese Philosophy. Princeton: Princeton University Press. 
Zhu, Xi 朱喜. 1986. Zhuzi Yulei 朱子語類 (Zhu's Classified Sayings). Beijing: Zhonghua shuju.

- 2002. Zhuzi Quanshu 朱子全書 (The Complete Works of Zhu Xi). Shanghai: Shanghai guji chubanshe.

.2003. Sishuzhangju Jizhu 四書章句集注 (A Collection of Comments on Sentences and Phrases in Four Books). Beijing: Zhonghua shuju. 